\title{
Genotypic, physiological and biochemical features of Desulfovibrio strains in a sulfidogenic microbial community isolated from the soil of ferrosphere
}

\author{
Nataliia Tkachuk ${ }^{1, *}$, Liubov Zelena², Pavlo Mazur'1, Oleksandr Lukash ${ }^{1}$ \\ T. H. Shevchenko National University "Chernihiv Collehium”, \\ Hetman Polubotko Str., 53, 14013, Chernihiv, Ukraine, \\ ${ }^{2}$ D.K. Zabolotny Insitute of Microbiology and Virology of the National Academy of Sciences of Ukraine, Zabolotny \\ Str., 154, 03143, Kyiv, Ukraine, \\ *corresponding author's e-mail: nataliia.smykun@gmail.com
}

Received: 25 March 2020 / Accepted: 20 April 2020

\begin{abstract}
The purpose of this work was the isolation of the predominant representatives of sulfate-reducing bacteria (SRB) of the sulfidogenic microbial community separated from the soil ferrosphere and the examination of their morphological, physiological, biochemical and genotypic peculiarities, the evaluation of some physiological processes under co-culturing with their satellite species Anaerotignum propionicum. During the study two isolates of sulfate-reducing bacteria NUChC SRB1 and NUChC SRB2 were obtained from sulfidogenic microbial community isolated from soil ferrosphere on Postgate's " $\mathrm{B}$ " medium and their belonging to different strains (using ISSR-PCR method) was proved. As a result of molecular-genetic analysis of the strains, a 16S rRNA gene fragments of $613 \mathrm{bp}$ and $522 \mathrm{bp}$ were amplified and sequenced. The strains were identified as Desulfovibrio oryzae by the complex of microbiological, physiological and biochemical features and on the basis of 16S rRNA gene sequences (phylogenetic analysis). The 16S rRNA gene sequences were submitted in GenBank as MT102713 (NUChC SRB1) and MT102714 (NUChC SRB2). The co-cultivation of isolated SRB strains with A. propionicum NUChC Sat1 strain (in the absence of electron donors, the presence of sulfates and yeast extract) showed the formation of sulfur-reducing bacteria of hydrogen sulfide, which was not observed during their mono-cultivation. In this case, the phenomenon of syntrophy probably takes place- co-growth on the nutrient substrate, and the electron donor appears due to the use of the yeast extract compounds by the NUChC Sat1 strain. Therefore, in the sulfidogenic community isolated from the soil ferrosphere, there is a mutual growth of the association of bacteria D. oryzae and A. propionicum, which is caused by trophic interaction. Possibly the contribution of these associated bacteria to the corrosion process lies in the utilization of hydrogen (D. oryzae) and the formation of substrate products of SRB metabolism (hydrogen and organic acids), which are both corrosive compounds (A. propionicum). Without a doubt the corrosion process involving this association needs further investigation.
\end{abstract}

Keywords: ferrosphere, sulfate-reducing bacteria, Desulfovibrio oryzae, 16S rRNA gene, ISSR-PCR.

\section{Introduction}

\section{Abbreviations}

ISSR-PCR - inter-simple sequence repeat polymerase chain reaction

MIC - microbiologically influenced corrosion

SRB - sulfate-reducing bacteria
In the soil that contacts with the surface of metal structures (in the ferrosphere), microbial communities develop. Sulfate-reducing bacteria (SRB) are permanent members of these communities (Beech \& Gaylarde, 1999; Marchal, 1999 ; Andreyuk et al., 2005). Hydrogen sulfide generated 
by them activates corrosion of metal structures and leads to undesirable environmental consequences (Beech \& Gaylarde, 1999; Marchal, 1999 ; Andreyuk et al., 2005).

Currently, sulphidogenic microbial community, consortia in which SRB are the dominant group, are actively involved in microbiologically influenced corrosion (MIC) (Beech \& Gaylarde, 1999; Marchal, 1999 ; Andreyuk et al., 2005; Purish \& Asaulenko, 2007). The study of the life processes of representatives of sulfidogenic community is important for the development and search of more effective measures against microbiologically influenced corrosion (Andreyuk et al., 2005).

In sulfidogenic community, sulfate-reducing bacteria participate in close interactions, particularly trophic ones, with bacteria of other physiological groups (Netrusov et al., 2004; Suarez et al., 2019). The most important trophic pathways in the anaerobic community to which the sulfidogen community belongs are hydrogen and acetate pathways (Netrusov et al., 2004).

Sulfidogens are linked by close trophic bonds to anaerobic heterotrophs using $\mathrm{H}_{2}$, organic acids and other metabolites of these bacteria (Peck \& Lissolo, 1988; Rozanova \& Nazina, 1989a). Hydrogen sulfide, hydrogen, organic acids are corrosive compounds of metabolites of SRB and heterotrophic organic acids-producing bacteria (Beech \& Gaylarde, 1999; Andreyuk et al., 2005) with which SRB are associated (Herro \& Port, 1993; AlAbbas et al., 2013). Machuca et al. (2017) have recently demonstrated that localised corrosion underneath a complex oilfield deposit was greatly accelerated by fermenting, thiosulphate-reducing bacteria. Bacteria with a fermentative type of metabolism can exert potential MIC reactions such as:

anodic reaction (iron oxidation) $\mathrm{Fe} \rightarrow \mathrm{Fe}^{2+}+2 \overline{\mathrm{e}}$;

cathodic reaction (proton reduction) $2 \mathrm{H}^{+}+2 \overline{\mathrm{e}} \rightarrow \mathrm{H}_{2}$;

chemical reaction $\mathrm{Fe}(\mathrm{s})+2 \mathrm{HAc} \rightarrow \mathrm{Fe}^{2+}+2 \mathrm{Ac}^{-}+\mathrm{H}_{2}$ (Dahle \& Birkeland, 2006; Duncan, 2010; Madigan et al., 2014; Li et al., 2018).

The inherent aggressiveness of MIC is thought to be due to the synergistic and syntrophic activities of microorganisms within a consortium. For decades, microbial syntrophic (cross-feeding) associations have been a topic of interest in the field of MIC (Suarez et al., 2019). Today the relationship between sulphate-reducing microorganisms and methanogens has been identified as an essential mechanism for corrosion (Deutzmann et al., 2015; Ozuolmez et al., 2015; Conlette, 2016).

At the same time, organic acid-producing bacteria from sulphidogenic microbial consortia have received little attention, despite their important role in such community, in particular as producers of nutrient substrates for SRB. At present, it is believed that acid-producing bacteria play only a minor role in microbiologically influenced corrosion processes (Gu, 2014).

Previously, anaerobic satellite of SRB - Anaerotignum (Clostridium) propionicum, which (by the characteristic of the species) forms organic acids and intensively produces $\mathrm{H}_{2}$ (Bergey's Manual of Systematic Bacteriology, 2009) was isolated (Tkachuk et al., 2018), but predominant representatives of the ecological-trophic group SRB of the sulfidogenic microbial community isolated from the soil ferrosphere were not obtained.

Therefore, the purpose of this work was the isolation of the predominant representatives of SRB of the sulfidogenic microbial community isolated from the soil ferrosphere and the examination of their morphological, physiological, biochemical and genotypic peculiarities, the evaluation of some physiological processes under co-culturing with their satellite species A. propionicum.

\section{Material and methods}

\subsection{Sample collection}

Soil sample, which was in direct contact with the surface of the metal structure (ferrosphere) was taken from a depth of $0.7 \mathrm{~m}$ and used to isolate of the pure bacterial cultures (Andreyuk et al., 2005). Sample was collected using sterile glass flask and was immediately transported to the laboratory and stored at $4{ }^{\circ} \mathrm{C}$ in the refrigerator.

\subsection{Organisms and growing conditions}

Pure cultures of NUChC SRB1 and NUChC SRB2 isolated from the sulfidogenic community of the soil ferrosphere by conventional method were used for the study (Romanenko \& Kuznetsov, 1974).

We also used a strain of organic acid-producing bacteria A. propionicum NUChC Sat1, previously isolated by us from the same sulfidogenic community (Tkachuk et al., 2018), which was submitted in GenBank as MG924747.

Investigation of the purity of cultures was performed by microscopy under a light microscope (Delta Optical Genetic Pro microscope) with immersion at magnification $x 1000$. Preparations-smears were made and stained with a solution of crystalline violet according to the simple conventional method (Pimenova et al., 1983).

The cultivation was carried out in liquid Postgate's "C" medium under anaerobic conditions, completely filling the tubes with medium and closing them with rubber stoppers. The incubation was carried out for 14 days at $29^{\circ} \mathrm{C}$. 


\subsection{Investigation of some microbiological and physiological-biochemical properties of the isolated strains of SRB}

The study of bacterial morphology was performed using light microscopy (Delta Optical Genetic Pro microscope) for magnification x 400 and x1000, and electron microscopy (electron microscope BS-540 (Tesla, Czechoslovakia) for magnification $\mathrm{x} 22000$.

Cells of microorganisms were stained by Gram's method in Kalina's modification (Dikiy et al., 2002). The morphological analysis of the colonies was carried out according to the conventional scheme. The ability of bacteria to form endospores was investigated by the conventional method (Pimenova et al., 1983). The investigations of the presence of catalase and oxidase were performed by conventional methods (Pimenova et al., 1983; Methods of General Bacteriology, 1984; Dikiy et al., 2002).

The ability of bacteria to use different electron donors such as organic acids (formate, acetate, propionate, lactate, fumarate and malate) and carbohydrates (glucose and fructose) was investigated. The compounds were added at a concentration of $5 \mu \mathrm{M}$ to Postgate's $« \mathrm{C} »$ medium without yeast extract (except for the formate in which the yeast extract was added in an amount of $1 \mathrm{~g} / \mathrm{L}$ medium).

The ability of bacteria to use different electron acceptors such as sulfate, sulfite, thiosulfate, fumarate in the amount of $4.5 \mathrm{~g} / \mathrm{L}$ (Asaulenko et al., 2010) and nitrate (in the form of $\mathrm{KNO}_{3}$ and at a concentration of $10 \mu \mathrm{M}$ ) (Peretyatko \& Gudz, 2011_Lwas investigated in Postgate's "C" medium. Ferum (II) sulfate was replaced by ferric (II) chloride. Anaerobic conditions were created by pouring the medium to the edges of the tubes and closing them with rubber stoppers. The cultivation temperature was $29^{\circ} \mathrm{C}$. Bacterial growth on medium with different electron donors and acceptors was evaluated visually by hydrogen sulfide formation and blackening of the medium.

\subsection{Molecular-genetic analysis of isolated strains}

To identify bacteria the sequencing and analysis of $16 \mathrm{~S}$ rRNA gene were carried out. DNA isolation, amplification with $27 \mathrm{~F}$ and $1492 \mathrm{r}$ primers, sequencing of $16 \mathrm{~S}$ rRNA gene using $27 \mathrm{~F}$ primer, phylogenetic analysis procedures were performed as described in (Tkachuk et al., 2017). The nucleotide sequences were deposited in GenBank as Desulfovibrio oryzae with accession numbers MT102713 (NUChC SRB1) and MT102714 (NUChC SRB2).

The basic sequence statistics of $16 \mathrm{~S}$ rDNA, including conserved sites, variable sites, parsimony informative sites, singleton sites and calculation of pairwise distances were analyzed with MEGA6 software (Tamura et al., 2013). Genome variability and strain differentiation were analyzed by ISSR-PCR (Inter-simple sequence repeat polymerase chain reaction). Total DNA was isolated from bacterial cell suspension using GeneJet Genomic DNA Purification Kit (ThermoScientific), according to manufacturer's procedure. PCR-mix (total volume $20 \mu \mathrm{l}$ ) consisted of $10 \mu \mathrm{l} 2 \mathrm{x}$ DreamTaq PCR Master Mix (ThermoScientific), 30 pmol primer and 30 ng DNA. Each PCR-mix contained only one primer to dinucleotide repeats: $(\mathrm{GA})_{9} \mathrm{C}$ or $(\mathrm{GA})_{8} \mathrm{~T}$. Amplification was carried out with the thermocycler Mastercycler Personal 5332 (Eppendorf, Germany) under the following conditions: one cycle $-95^{\circ} \mathrm{C}, 2 \mathrm{~min} ; 45$ cycles $-95^{\circ} \mathrm{C}$, $30 \mathrm{sec} ; 52^{\circ} \mathrm{C}, 45 \mathrm{sec} ; 72^{\circ} \mathrm{C}, 2 \mathrm{~min}$; final extension $-72^{\circ} \mathrm{C}$, $7 \mathrm{~min}$. PCR products were electrophoretically separated on a $1.7 \%$ TBE-agarose gel in TBE buffer and stained with ethidium bromide. Results were visualized under UV-light.

\subsection{The investigation of the growth of SRB NUChC SRB1 and NUChC SRB2 co-cultured together with A. propionicum NUChC Sat1 on a medium without electron donors}

5-days cultures with an optical density of $0.5 \mathrm{McF}$ arland were used. $1 \mathrm{ml}$ of bacterial suspension was added to tubes with Postgate's "C" medium (with sulfates and yeast extract without the addition of electron donor) as monocultures and their associations (NUChC Sat1 + NUChC SRB1 and NUChC Sat1 + NUChC SRB2). The growth of the cultures was evaluated visually by the turbidity of the medium and the formation of hydrogen sulfide. A sterile Postgate's "C" medium with sulfates, yeast extract and without electron donor served as a control. The cultivation was carried out under anaerobic conditions, pouring the medium to the edges of the tubes and closing them with rubber stoppers. The incubation was carried out for 14 days at $29^{\circ} \mathrm{C}$.

\section{Results and discussion}

\subsection{Microbiological properties of strains}

During the investigation, two clear black SRB colonies with a diameter of $1 \mathrm{~mm}$ (NUChC SRB1 isolate) and $2 \mathrm{~mm}$ (NUChC SRB2 isolate) were isolated in Postgate's "B" medium in a sulfidogenic microbial community isolated from the soil ferrosphere (Fig. 1). After repeated replanting on Postgate's liquid and agar medium, two cultures were found to be pure and used in the further studies. 
The shape of both colonies is round, the texture is soft. Bacteria NUChC SRB1 and NUChC SRB2 are mobile vibrios with rounded ends, $4.6 \pm 0.3 \mu \mathrm{m}$ and $1.8 \pm 0.1 \mu \mathrm{m}$ in length, respectively, monotrichs (Fig. 2). The cells are gram-negative (Fig. 3). Both isolates are catalase-negative, oxidase-positive. The endospores are not formed.

Therefore, microbiological characteristics according to Bergey's Manual of Systematic Bacteriology (Bergey's Manual of Systematic Bacteriology, 2005) prove that the isolated bacteria can belong to the Desulfovibrionaceae family.

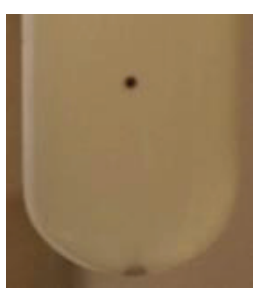

a

\subsection{Identification of isolates by $16 \mathrm{~S}$ rRNA gene sequence analysis}

To define taxonomic and systematic position of bacteria as a general rule sequencing and detailed analysis of $16 \mathrm{~S}$ rDNA are exploited. Isolates of the same genus represent more than $95 \%$ similarity and those of the same species more than 98\% (Stackebrandt \& Ebers, 2006).

As a result of $16 \mathrm{~S}$ rRNA gene sequencing 613-bp (NUChC SRB1) and 522-bp (NUChC SRB2) nucleotide fragments were obtained and compared with known $16 \mathrm{~S}$ rRNA gene sequences from GenBank. 98-99\% similarity

Figure 1. Colonies SRB on Postgate's «B» agar medium (5th day of cultivation): $a$ - isolate NUChC SRB1; $b$ - NUChC SRB2 isolate

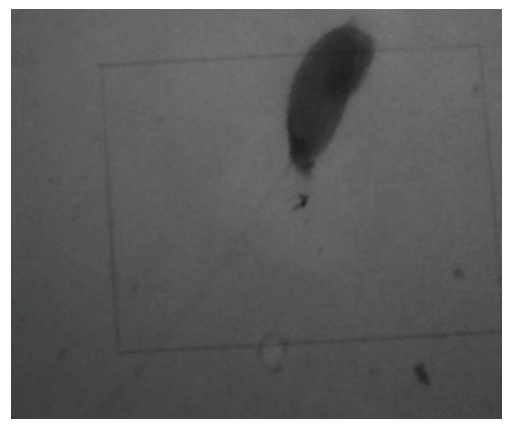

a

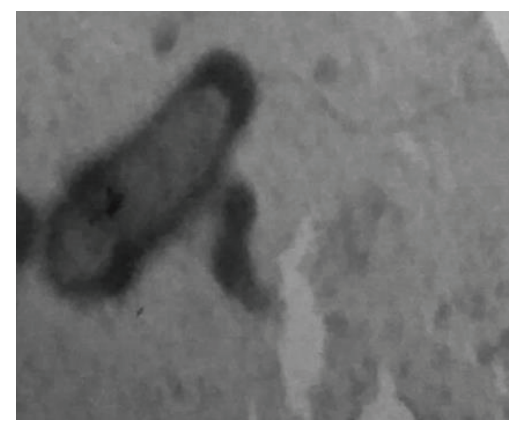

b

Figure 2. Electronic microphotographs of bacteria: (a) NUChC SRB1 and (b) NUChC SRB2 (magnification x22000)

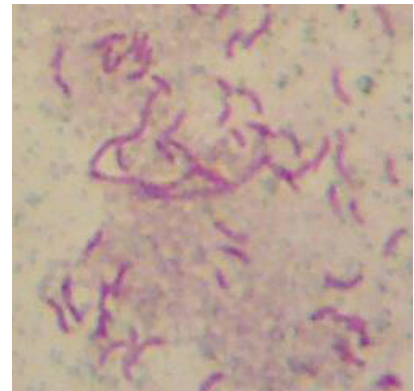

a

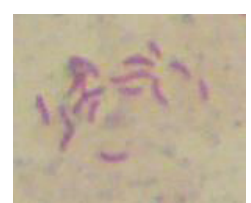

b

Figure 3. Microphotographs of SRB cells: (a) NUChC SRB1 and (b) NUChC SRB2 (staining by Gram's method in Kalina's modification, light microscopy, immersion, x1000) 
was revealed between NUChC SRB1 or NUChC SRB2 and strains representing various species of Desulfovibrio genus such as D. longreachensis, D. termitidis, D. oxamicus, D. vulgaris while the percent identity between two analyzed strains NUChC SRB1 and NUChC SRB2 was $99.6 \%$ with the query coverage of $85 \%$.

To analyze nucleotide diversity within $16 \mathrm{~S}$ rRNA gene fragment the basic sequences statistics between 9 representatives of Desulfovibrio genus was also performed. It included type strains of $D$. longreachensis, D. termitidis, $D$. oxamicus, D. vulgaris, D. oryzae, D. burkinensis, D. aminophilus and two new isolated strains - NUChC SRB1 and NUChC SRB2. The aligned 16S rDNA sequences were trimmed and compared. The length of fragments varied from $521 \mathrm{bp}$ to $527 \mathrm{bp}$ with an average size of $523 \mathrm{bp}$. The percentage of variable sites accounted $21 \%, 5 \%$ were parsimony informative sites and $15 \%$ represented singleton sites. Since parsimony informative and singleton sites between NUChC SRB1 and NUChC SRB2 were not detected it might indicate that the studied isolates belong to the same species.

To infer relationships between different species of $D e$ sulfovibrio genus the pairwise distances of 8 Disulfovibrio strains were calculated and a phylogenetic tree on the basis of $16 \mathrm{~S}$ rDNA sequences was constructed (Fig. 4). The lowest values of genetic distance were detected between D. oryzae type strain and new isolates, the highest values between $D$. aminophilus and the rest strains.

There were 2 clusters of Desulfovibrio species on the dendrogram. The first cluster consisted of D. oryzae group, type strain and 2 new isolated strains NUChC SRB1, NUChC SRB2, combined with D. longreachensis type strain. The second cluster was formed of D. oxamicus and D. termitidis type strains. These clusters joined together and differentiated from the others Desulfovibrio species -
D. vulgaris, D. burkinensis and D. aminophilus. Thus, the classification of Desulfovibrio species on the dendrogram defined new isolates as D. oryzae.

Thus, on the basis of complex molecular-genetic features, $D$. oryzae is the closest species to the new strains.

It should be noted that the $D$. oryzae species is currently poorly studied. In the literature available to us there is only one brief description of the species (Salgar-Chaparro \& Silva-Plata, 2008). Some D. oryzae strains have been isolated from a community of oil-related water associated with the corrosion process (Salgar-Chaparro \& Silva-Plata, 2008; Duque et al., 2011).

In general, bacteria of the Desulfovibrio genus are the best-known examples of SRB which have been considered to be the most common stimulants of bio-corrosion (Chang et al., 2014).

Thus, the work of Purish et al. (2014) shows the development of sulfate-reducing bacteria, which differ in morphological and physiological properties, in areas of urban district heating systems in different temperature operating conditions. At the sites operated at temperatures of $35-$ $45^{\circ} \mathrm{C}$, the authors found bacteria of the genus Desulfovibrio, and at the sites with a temperature of $60^{\circ} \mathrm{C}$ - bacteria of the genus Desulfotomaculum and Desulfomicrobium were detected.

Unfortunately, researchers of microbiologically influenced corrosion often do not perform species-specific bacterial identification, focusing on generic identification. It ought to be remarked that the identification and biochemical characteristic of the properties of microbes isolated from microbiologically influenced corrosion is important because the knowledge of the species of microorganisms and their mechanisms of action is the basis for the detection, monitoring or control of MIC (Kan et al., 2011).

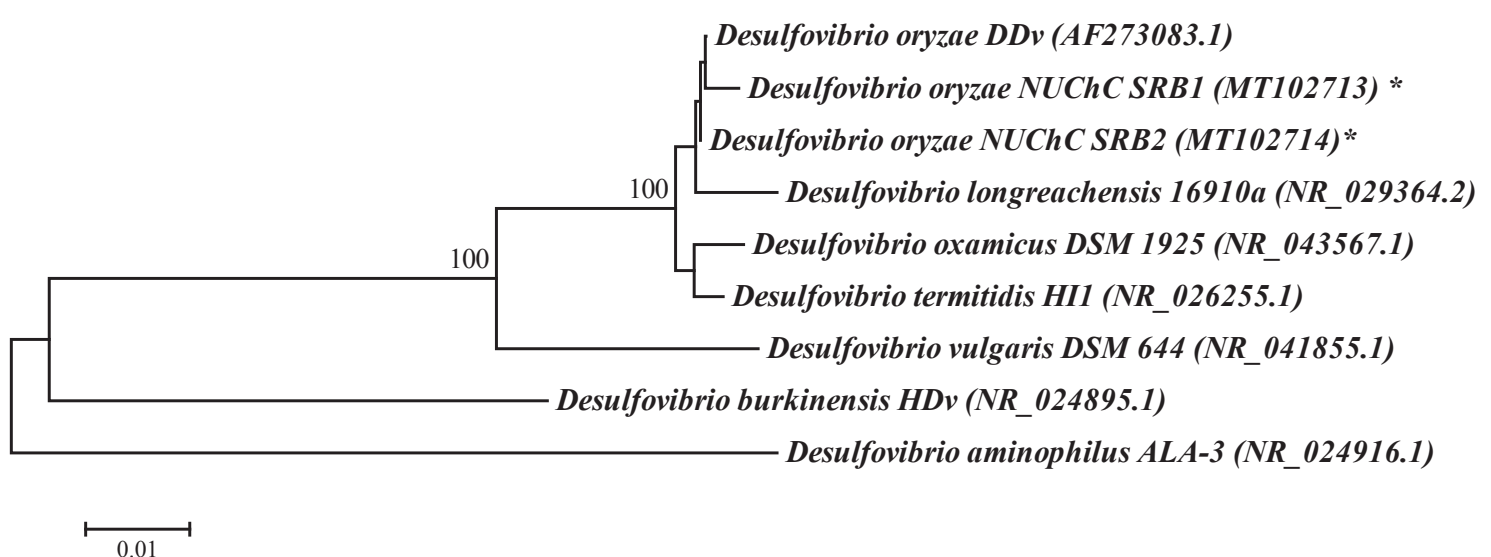

Figure 4. Results of phylogenetic analysis of the studied isolates and other representatives of the Desulfovibrionaceae family. The test isolates are indicated by an asterisk 
For species-specific identification of SRB, in particular Desulfovibrio species, research on the use of electron donors and acceptors is crucial (Bergey's Manual of Systematic Bacteriology, 2005).

\subsection{Use of electron donors and acceptors by the studied SRB}

The results of the study of the use of donors and electron acceptors by the studied isolates and their comparison with bacteria $D$. longreachensis, D. termitidis, D. oxamicus and D. oryzae (Trinkerl et al., 1990; Redburn \& Patel, 1994; Bergey's Manual of Systematic Bacteriology, 2005; LópezCortés et al., 2006; Salgar-Chaparro \& Silva-Plata, 2008; Kuever, 2014) are summarized in the Table 1.

It was found that the isolates under the study are able to use lactate and formate as electron donors. Acetate, fumarate, propionate, malate, fructose and glucose are not used as electron donors. As electron acceptors, the NUChC
SRB1 isolate uses sulfate and thiosulfate, but does not use sulfite, fumarate and nitrate. NUChC SRB2 isolate uses sulfate, thiosulphate and fumarate as electron acceptors, but does not use sulfite and nitrate.

Thus, according to the complex of cultural-morphological, physiological-biochemical and genetic signs, SRB isolates NUChC SRB1 and NUChC SRB2 are classified as Desulfovibrio oryzae.

\subsection{Genome variability of new isolates}

Bacterial genomes contain a variety of nucleotide repeats that can be part of coding as well as non-coding sequences. Nucleotide repeats differ in their size of the repeating unit, the length or number of repeats, orientation, location, etc. (Smirnov, 2010). The satellite DNA can be defined depending on the size of repeating unit as micro-, mini- and macrosatellites. ISSR-PCR analysis was carried out in our study to evaluate genome variability and differentiate the

Table 1. The use of some compounds as electron donors and acceptors by isolates of Desulfovibrio sp. NUChC SRB1 and Desulfovibrio sp. NUChC SRB2

\begin{tabular}{|c|c|c|c|c|c|c|}
\hline Compound & 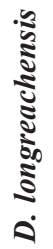 & 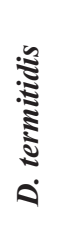 & 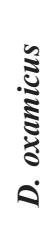 & $\begin{array}{c}\stackrel{0}{5} \\
\stackrel{5}{3} \\
\stackrel{5}{0}\end{array}$ & 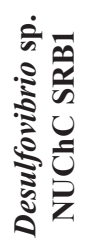 & 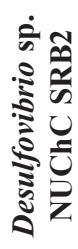 \\
\hline \multicolumn{7}{|c|}{ The electron donor } \\
\hline Formate & nd & $+*$ & $+*$ & nd & $+*$ & $+*$ \\
\hline Acetate & - & - & - & - & - & - \\
\hline Lactate & + & + & + & + & + & + \\
\hline Fumarate & + & nd & - & + & - & - \\
\hline Propionate & - & nd & nd & nd & - & - \\
\hline Malate & - & - & nd & nd & - & - \\
\hline Fructose & nd & + & - & nd & - & - \\
\hline Glucose & nd & + & - & nd & - & - \\
\hline \multicolumn{7}{|c|}{ The electron acceptor } \\
\hline Sulfate & + & + & + & + & + & + \\
\hline Sulfite & + & + & nd & nd & - & - \\
\hline Thiosulfate & + & + & nd & + & + & + \\
\hline Fumarate & + & nd & nd & - & - & + \\
\hline Nitrate & nd & + & + & - & - & - \\
\hline
\end{tabular}

Note: "+" - the sign is inherent; "-" - the sign is not inherent; "nd" - not determined; "“*” - in the presence of yeast extract. 
new D. oryzae strains by assessing distribution of microsatellite repeats in bacterial genome. For this purpose amplification with primers to short repeats, with the size of the repeating unit 2 nucleotides, was performed. Dinucleotide repeats are among the most changeable in numbers repeats and thus represents the highly polymorphic genome regions. ISSR-markers are widely used in gene mapping studies, genotyping bacterial species and strains, phylogenetic and taxonomic researches (Zelena et al., 2011).

The results of PCR-analysis showed that each sample was characterized by specific set of amplicons suggesting the differences in the distribution of dinucleotide repeats in the primary DNA sequence of strains, and, consequently, distinguishing samples and defining them as different strains. In general, the total amplicon pattern when amplified with primer (GA) $\mathrm{C}$ consisted of 10 fragments, ranging in size from 400 to $3000 \mathrm{bp}$, and with primer (GA) ${ }_{8} \mathrm{~T}-$ 12 PCR-products the size of which varied within $300-$ 3000 bp. (see Fig. 5). Therefore, the new isolated SRB belong to different strains.

The most corrosive damages are observed in the presence of multispecies communities. Researchers say that several microorganisms that cause corrosion in the biofilm can act synergistically and promote stronger corrosion than in the presence of only a single species (Zuo, 2007; Lee et al., 2013).

\subsection{The growth of the tested SRB strains co-cultured together with A. propionicum NUChC Sat1}

Further, during the study, the development of isolated strains of sulfate-reducing bacteria $D$. oryzae NUChC SRB1 and D. oryzae NUChC SRB2 on Postgate's "C" medium (with sulfates, yeast extract and without electron donor) was visually evaluated both in the form of monocultures and associations with $A$. propionicum NUChC Sat1. The results of the study are summarized in the Table 2 .

It was found that all the tested strains are able to grow on a Postgate's "C" medium with sulfates and yeast extract without electron donors. However, sulfate reduction in SRB of NUChC SRB1 and NUChC SRB2 strains in monocultures was not observed under these conditions. In the presence of yeast extract without electron donor strains probably grow fermentatively using for this yeast extract, and are not capable of sulfate reduction.

During co-cultivation of the NUChC Sat1 strain with the NUChC SRB1 and NUChC SRB2 strains both SRB development and hydrogen sulfide formation were observed. This indicates the appearance of an electron donor in the medium, which is used by the SRB for the sulfate reduction process. As it is known yeast extract includes watersoluble yeast cell components, which are composed mainly

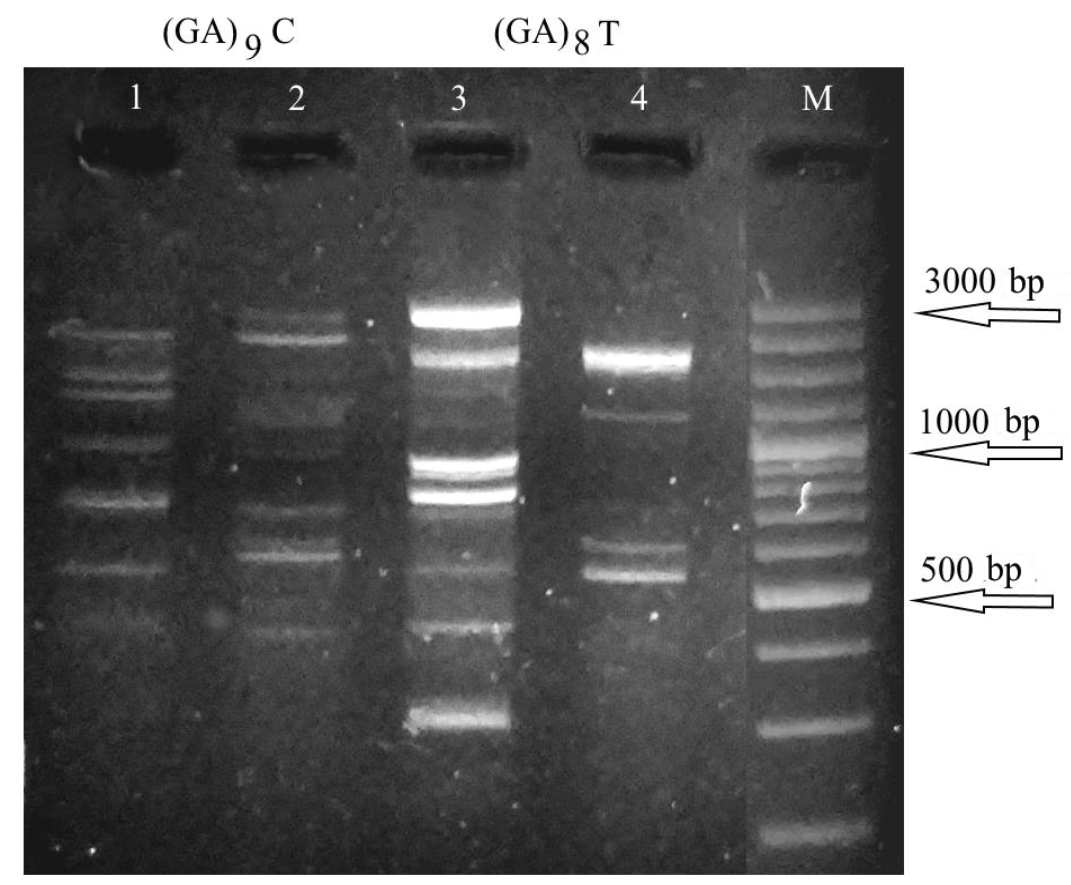

Figure 5. Results of ISSR-PCR analysis / Electrophoregram of PCR with primers to short nucleotide repeats: $\mathrm{M}$ - DNA ladder (ThermoScientific); 1, 3 - NUChC SRB1; 2, 4 - NUChC SRB2 
Table 2. Visual signs of bacterial development

\begin{tabular}{|c|c|c|}
\hline \multirow{2}{*}{ An experiment option } & \multicolumn{2}{|c|}{ Sign } \\
\cline { 2 - 3 } & Turbidity & $\begin{array}{c}\text { Hydrogen sulfide } \\
\text { formation }\end{array}$ \\
\hline Control & - & - \\
\hline NUChC Sat1 & + & - \\
\hline NUChC SRB1 & + & - \\
\hline NUChC SRB2 & + & $+\mathrm{w}$ \\
\hline NUChC Sat1 + NUChC SRB1 & + & $+\mathrm{w}$ \\
\hline NUChC Sat1 + NUChC SRB2 & + & \\
\hline
\end{tabular}

Note: "+”- marked; “_" - not marked; "w" - weakly.

of amino acids, peptides, carbohydrates and salts (Yeast Extract. URL: http://hefeextrakt.info/public/documents/ yeast-products/yeast_extract.pdf).

Apparently, A. propionicum NUChC Sat1 utilizes these compounds in the process of metabolism and forms metabolites (in particular $\mathrm{H}_{2}$ ), which are electron donors for sulfate reduction process of the NUChC SRB1 and NUChC SRB2. In this case, the phenomenon of syntrophy is probably observed - mutual growth on the nutrient substrate (Netrusov et al., 2004).

The growth of Desulfovibrio strains due to fermentation (in the absence of oxidized sulfur compounds, nitrate and nitrite) or in syntrophic cultures is analyzed in work (Rozanova \& Nazina, 1989b). In particular, the authors refer to the work of Phelps et al., 1985, which identified a change in metabolism aimed at intensification of hydrogen formation in the associations of $D$. vulgaris and Methanosarcina barkeri cultures. They noted a new type of associative bonds when due to the influence of a sulfate-reducing satellite, which catches the medium product, the direction of the catabolic process of another member of the association changes.

\section{Conclusions}

Thus, two isolates of sulfate-reducing bacteria NUChC SRB1 and NUChC SRB2 were obtained from sulfidogenic microbial community isolated from soil ferrosphere on Postgate's "B" medium and their belonging to different strains was proved. According to the complex of culturalmorphological, physiological-biochemical and genetic traits, the strains NUChC SRB1 and NUChC SRB2 are classified as Desulfovibrio oryzae.
Co-cultivation of the studied strains with Anaerotignum propionicum NUChC Sat1 (without of electron donors, the presence of sulfates and yeast extract) showed the formation by sulfur-reducing bacteria of hydrogen sulfide, which was not observed in the case of cultivation of monocultures. In this case a phenomenon of syntrophy seems to take place and the electron donor appears due to the use of the yeast extract compounds by the NUChC Sat1 strain.

Therefore, in the sulfidogenic community isolated from the soil ferrosphere, there is a mutual growth of the association of bacteria Desulfovibrio oryzae and Anaerotignum propionicum, which is caused by trophic interaction. Possibly the contribution of these associated bacteria to the corrosion process lies in the utilization of hydrogen $(D$. oryzae) and the formation of substrate products of SRB metabolism (hydrogen and organic acids), which are both corrosive compounds (A. propionicum). The corrosion process with the involvement of this association needs further investigation.

\section{Acknowledgements}

We sincerely grateful to the leading engineer Volodymyr Strekalov (Institute of Agricultural Microbiology and Agroindustrial Production of National Academy of Agricultural Sciences of Ukraine) for carrying out electronic microscopy, the students Maryna Stepko and Oleksii Tonkanov (T.H.Shevchenko National University "Chernihiv Colehium") for excellent technical assistance. 


\section{References}

AlAbbas F.M., Williamson Ch., Bhola Sh.M., Spear J.R., Olson D.L., Mishra B. \& Kakpovbia A.E., 2013, Microbial Corrosion in Linepipe Steel Under the Influence of a Sulfate-Reducing Consortium Isolated from an Oil Field. J. Mater. Eng. Perform. 22(11): 3517-3529.

Andreyuk K., Kozlova I., Koptieva Zh., PilyashenkoNovokhatny A., Zanina V. \& Purish L. 2005, Microbial Corrosion of Underground Structures, Nauk. Dumka, Kyiv, 258 pp.

Asaulenko L.G., Abdulina D.R. \& Purish L.M., 2010, Taxonomic position of individual representatives of sulfidogenic corrosion-aggressive microbial community. Mikrobiol. Z. 72(4): 3-10.

Beech I.B. \& Gaylarde Ch.C., 1999, Recent advances in the study of biocorrosion: an overview. Rev. Microbiol. 30(3): 117-190.

Bergey's Manual of Systematic Bacteriology [Don J. Brenner, Noel R. Krieg, James T. Staley et al.], 2005, Second Edition, 2, The Proteobacteria, Part C. The Alpha-, Beta-, Delta-, and Epsilonproteobacteria. Springer, New York, 1388 pp.

Bergey's Manual of Systematic Bacteriology [Paul De Vos, George M. Garrity, Dorothy Jones et al.], 2009, Second edition. The Firmicutes, Springer, New York, 1422 pp.

Chang Y.J., Chang Y.T., Hung C.H., Lee J.W., Liao H.M. \& Chuo H.L., 2014, Microbial community analysis of anaerobic bio-corrosion in different ORP profiles. Int. Biodeterior. Biodegrad. 95: 93-101.

Conlette O.C., 2016, Microbial communities of light crude from Nigeria and potential for in situ biodegradation, souring, and corrosion. Petrol. Sci. Technol. 34: 71-77.

Dahle H. \& Birkeland N.-K., 2006, Thermovirga lienii gen. nov., sp. nov., a novel moderately thermophilic, anaerobic, amino-acid-degrading bacterium isolated from a North Sea oil well Int. J. Syst. Evol. Microbiol. 56: $1539-1545$.

Deutzmann J.S., Sahin M. \& Spormann A.M., 2015, Extracellular enzymes facilitate electron uptake in biocorrosion and bioelectrosynthesis. mBio 6 .

Dikiy I.L., Holupyak I.Y. \& Sidorchuk I.I., 2002, Microbiology. Laboratory Manual, National University of Pharmacy Publishing House "Golden Pages", Kharkov, 444 pp.

Duncan K.E., 2010, Biocorrosive thermophilic microbial communities in alaskan north slope oil facilities. Environ. Sci. Technol. 43: 7977-7984.

Duque Z., Ibars J.R., Sarro' M.I. \& Moreno D.A., 2011, Comparison of sulphide corrosivity of sulphate- and non-sulphate-reducing prokaryotes isolated from oil- field injection water. Materials and Corrosion 62(9999): 1-7.

Gu T., 2014, Theoretical Modeling of the Possibility of Acid Producing Bacteria Causing Fast Pitting Biocorrosion. J. Microb. Biochem. Technol. 6(2): 068-074.

Herro H.M. \& Port R.D., 1993, The Nalco guide to cooling water system failure analysis. McGraw-Hill, New York.

Kan J., Chellamuthu P., Obraztsova A., Moore J.E. \& Nealson K.H., 2011, Diverse bacterial groups are associated with corrosive lesions at a Granite Mountain Record Vault (GMRV). Journal of Applied Microbiology 111: 329-337.

Kuever J., 2014, The family Desulfovibrionaceae, [in:] E. Rosenberg, E.F. DeLong, S. Loy, E. Stackebrandt, F. Thompson (eds), The Prokaryotes. Deltaproteobacteria and Epsilonproteobacteria, Fourth Edition. Springer-Verlag Berlin Heidelberg, p. 107-142.

Lee J.S., McBeth J.M., Ray R.I., Little B.J. \& Emerson D., 2013, Iron cycling at corroding carbon steel surfaces. Biofouling 29: 1243-1252.

Li Y., Xu D., Chen C., Li X., Jia R., Zhang D., Sand W., Wang F. \& Gu T., 2018, Anaerobic microbiologically influenced corrosion mechanisms interpreted using bioenergetics and bioelectrochemistry: a review. J. Mater. Sci. Technol. 34: 1713-1718.

López-Cortés A., Fardeau M.L., Fauque G., Joulian C. \& Ollivier B., 2006, Reclassification of the sulphate- and nitrate-reducing bacterium Desulfovibrio vulgaris subsp. oxamicus as Desulfovibrio oxamicus sp. nov., comb. nov. Int. J. Syst. Evol. Microbiol. 56: 1495-1499.

Machuca L.L., Lepkova K. \& Petroski A., 2017, Corrosion of carbon steel in the presence of oilfield deposit and thiosulphate-reducing bacteria in $\mathrm{CO}_{2}$ environment. Corrosion Sci. 129: 16-25.

Madigan M.T., Martinko J.M., Bender K.S., Buckley D.H. \& Stahl D.A., 2014, Brock Biology of Microorganisms, fourteenth ed. Pearson Education Ltd., Boston.

Marchal R., 1999, Rôle des bacteriés sulfurogènes dans la corrosion du fer. Oil \& Gas Science and Technology: Rev. IFP 54(5) : 649-659.

Methods of General Bacteriology: in three volumes, Vol.3, 1984, F. Gerhardt et al. (ed.). Mir, Moscow, 264 pp.

Netrusov A.I., Bonch-Osmolovskaya E.A., Gorlenko V.M., Ivanov M.V., Karavayko G.I., Kozhevin P.A., Kolotilova N.N., Kotova I.B., Maksimov V.N., Nozhevnikova A.N., Semenov A.M., Turova T.P. \& Yudina T.G., 2004, Ecology of microorganisms, A.I. Netrusov (ed.). Academia Publishing Center, Moscow, 272 pp.

Ozuolmez D., Na H., Lever M.A., Kjeldsen K.U., Jorgensen B.B. \& Plugge C.M., 2015, Methanogenic archaea and sulfate reducing bacteria co-cultured on acetate: teamwork or coexistence? Front. Microbiol. 6: 492. 
Peck Jr. H.D. \& Lissolo T., 1988, Assimilatory and dissimilatory sulphate reduction: enzymology and bioenergetics, [in:] J.A. Cole, S.J. Ferguson (eds), The Nitrogen and Sulphur Cycles, 42. Cambridge University Press, Canbridge, p. 99-132.

Peretyatko T.B. \& Gudz S.P., 2011, The ability of sulfatereducing bacteria Desulfovibrio desulfuricans Ya11 and Desulfobacter sp. use nitrate as an electron acceptor. Biol. Stud. 5(2): 51-60.

Pimenova M.N., Grechushkina N.N., Azova L.G., Semenova E.V. \& Mylnikova S.I., 1983, Guide to Microbiology Practical Practices: Pract. Manual; N.S. Egorov (ed.). Publishing House of the Moscow University, Moscow, $215 \mathrm{pp}$.

Purish L.M. \& Asaulenko L.G., 2007, Dynamics of succession changes in sulfidogenic microbial association under conditions of biofilm formation on the surface of steel. Mikrobiol. Z. 69(6): 19-25.

Purish L.M., Asaulenko L.G., Abdulina D.R. \& Iutinskaya G.A., 2014, Biodiversity of sulfate-reducing bacteria developing on heat facilities. Mikrobiol. Z. 76(3): 1117.

Redburn A.C. \& Patel B.K.C., 1994, Desulfovibrio longreachii $\mathrm{sp}$. nov., a sulfate-reducing bacterium isolated from the Great Artesian Basin of Australia. FEMS Microbiology Letters 115: 33-38.

Romanenko V.I. \& Kuznetsov S.I., 1974, Ecology of microorganisms of fresh water bodies. Nauka, Leningrad, 193 pp.

Rozanova E.P. \& Nazina T.N., 1989a, Sulfate-reducing bacteria (systematics and metabolism). Microbiology 51: 191-226.

Rozanova E.P. \& Nazina T.N., 1989b, Modern concepts of sulfate-reducing bacteria, [in:] Chemosynthesis: On the 100th anniversary of the discovery by S.N. Vinogradsky, Moscow, p. 199-228.

Salgar-Chaparro S.J. \& Silva-Plata B.A., 2008, Caracterizacion de la comunidad microbiana residente en aguas de produccion de tres campos de explotacion petrolera, con especial enfasis en grupos asociados a procesos corrosivos. Proyecto. Universidad Industrial de Santander: 30 .
Smirnov G.V., 2010, Repeats in bacterial genome: evolutionary considerations. Microbiology and Virology 25(2): 56-65.

Stackebrandt E. \& Ebers J., 2006, Taxonomic parameters revisited: tarnished gold standards. Microbiology today 33(4): 152-155.

Suarez E.M., Lepkova K., Kinsella B. \& Machuca L.L., 2019, Aggressive corrosion of steel by a thermophilic microbial consortium in the presence and absence of sand. International Biodeterioration \& Biodegradation 137: 137-146.

Tamura K., Stecher G., Peterson D., Filipski A. \& Kumar S., 2013, MEGA6: Molecular Evolutionary Genetics Analysis Version 6.0. Molecular Biology and Evolution 30: 2725-2729.

Tkachuk N.V., Zelena L.B., Parminska V.S., Yanchenko V.O. \& Demchenko A.M., 2017, Identification of heterotrophic soil ferrosphere bacteria and their susceptibility to pesticide linuron. Mikrobiol. Z. 79(4): 75-87.

Tkachuk N., Zelena L. \& Garkavenko K., 2018, Selection and identification of anaerobic satellite of sulfaterenewing bacteria [in:] «Shevchenkivsky spring: achievements of biological science / BioScience Advances»: Proceedings of the XVI International Scientific Conference of Students and Young Scientists Kyiv, April 24-27, 2018). A.V. Palivoda, Kyiv, p. 106107.

Trinkerl M., Breunig A., Schauder R. \& Konig H., 1990, Desulfovibrio termitidis sp. nov., a carbohydrate-degrading sulfate-reducing bacterium from the hindgut of a termite. System. Appl. Microbiol. 13: 372-377.

Yeast Extract. URL: http://hefeextrakt.info/public/documents/yeast-products/yeast_extract.pdf.

Zelena L.B., Kovalenko N.K. \& Poltavska O.A., 2011, Intraspecies variability of bifidobacteria colonizing human gastro-intestinal tract. Mikrobiol. Z. 73(3): 9-13.

Zuo R., 2007, Biofilms: strategies for metal corrosion inhibition employing microorganisms. Appl. Microbiol. Biotechnol. 76: 1245-1253. 